Article

\title{
Viral Infection and Respiratory Exacerbation in Children: Results from a Local German Pediatric Exacerbation Cohort
}

\author{
Erwan Sallard ${ }^{1,+}+{ }^{D}$, Frank Schult ${ }^{2,+}$, Carolin Baehren ${ }^{3}$, Eleni Buedding ${ }^{3}$, Olivier Mboma ${ }^{2}$, Parviz Ahmad-Nejad ${ }^{4}$, \\ Beniam Ghebremedhin ${ }^{4, \ddagger} \mathbb{D}$, Anja Ehrhardt ${ }^{1}$, Stefan Wirth ${ }^{2}$ and Malik Aydin ${ }^{2,3, *}$
}

1 Center for Biomedical Education and Research (ZBAF), Department of Human Medicine, Faculty of Health, Institute of Virology and Microbiology, Witten/Herdecke University, 58453 Witten, Germany; erwan.sallard@uni-wh.de (E.S.); anja.ehrhardt@uni-wh.de (A.E.)

2 Center for Child and Adolescent Medicine, Center for Clinical and Translational Research (CCTR), Helios University Hospital Wuppertal, Witten/Herdecke University, 42283 Wuppertal, Germany; frank.schult@helios-gesundheit.de (F.S.); olivier.mboma@uni-wh.de (O.M.); stefan.wirth@uni-wh.de (S.W.)

3 Laboratory of Experimental Pediatric Pneumology and Allergology, Center for Biomedical Education and Research, Faculty of Health, School of Life Sciences (ZBAF), Witten/Herdecke University, 58455 Witten, Germany; carolin.baehren@uni-wh.de (C.B.); eleni.buedding@uni-wh.de (E.B.)

4 Institute for Medical Laboratory Diagnostics, Center for Clinical and Translational Research (CCTR), Helios University Hospital Wuppertal, Witten/Herdecke University, 42283 Wuppertal, Germany; parviz.ahmad-nejad@helios-gesundheit.de

* Correspondence: malik.aydin@uni-wh.de; Tel.: +49-(0)-202-896-2384; Fax: +49-(0)-202-896-3834

+ These authors contributed equally to this work.

$\ddagger$ Professor Ghebremedhin unfortunately passed away during the submission of this manuscript. In deep mourning and memory, we would like to dedicate this work to him.

\section{check for}

updates

Citation: Sallard, E.; Schult, F.;

Baehren, C.; Buedding, E.; Mboma,

O.; Ahmad-Nejad, P.; Ghebremedhin,

B.; Ehrhardt, A.; Wirth, S.; Aydin, M.

Viral Infection and Respiratory

Exacerbation in Children: Results

from a Local German Pediatric

Exacerbation Cohort. Viruses 2022, 14

491. https://doi.org/10.3390/

v14030491

Academic Editor: Gary McLean

Received: 9 February 2022

Accepted: 23 February 2022

Published: 27 February 2022

Publisher's Note: MDPI stays neutral with regard to jurisdictional claims in published maps and institutional affiliations.

Copyright: (C) 2022 by the authors. Licensee MDPI, Basel, Switzerland. This article is an open access article distributed under the terms and conditions of the Creative Commons Attribution (CC BY) license (https:// creativecommons.org/licenses/by/ $4.0 /)$.

\begin{abstract}
Respiratory viruses play an important role in asthma exacerbation, and early exposure can be involved in recurrent bronchitis and the development of asthma. The exact mechanism is not fully clarified, and pathogen-to-host interaction studies are warranted to identify biomarkers of exacerbation in the early phase. Only a limited number of international exacerbation cohorts were studied. Here, we have established a local pediatric exacerbation study in Germany consisting of children with asthma or chronic, recurrent bronchitis and analyzed the viriome within the nasopharyngeal swab specimens derived from the entire cohort $(n=141)$. Interestingly, $41 \%$ of exacerbated children had a positive test result for human rhinovirus (HRV)/human enterovirus (HEV), and 14\% were positive for respiratory syncytial virus (RSV). HRV was particularly prevalent in asthmatics $(56 \%)$, wheezers $(50 \%)$, and atopic $(66 \%)$ patients. Lymphocytes were decreased in asthmatics and in HRV-infected subjects, and patients allergic to house dust mites were more susceptible to HRV infection. Our study thus confirms HRV infection as a strong 'biomarker' of exacerbated asthma. Further longitudinal studies will show the clinical progress of those children with a history of an RSV or HRV infection. Vaccination strategies and novel treatment guidelines against HRV are urgently needed to protect those high-risk children from a serious course of disease.
\end{abstract}

Keywords: human rhinovirus; respiratory syncytial virus; virus; infection; asthma; bronchitis; exacerbation; children

\section{Introduction}

Asthma is still one of the most common respiratory diseases [1,2], with 262 to 340 million cases worldwide, including 800,000 affected children living in Germany and a region-dependent incidence [3-8] associated with a high number of undiagnosed cases [9-12]. Based on the German national guidelines, the NVL Asthma 2020 (=Nationale Versorgungsleitlinie Asthma 2020), severe asthma exacerbation is defined by tachypnea, tachycardia, peak expiratory flow variations, reduced oxygen saturation, or speech dyspnea [13]. In addition to environmental factors [14,15], viral infections also play a leading role in asthma exacerbation [16-20]. Depending 
on the virus, an infection can influence the clinical course and may lead to an alarming increase in morbidity and mortality when appropriate interventions are not successfully initiated [21-28]. Despite vastly improved therapeutic possibilities, asthma mortality still remains tragically high with 461,000 deaths in 2019 [6].

While mortality, severity, and prevalence vary widely geographically, the prevalence of this disease in Germany is estimated to be approximately $5 \%$ in adults and $10 \%$ in children [29-33]. Asthma remains one of the costliest disorders and imposes a significant burden on society and patients, resulting in 11.0 million physician visits and 1.7 million emergency room visits, and is the leading cause of missed school days [29,34-36].

Past studies reported that human rhinovirus (HRV) [37-40] or respiratory syncytial virus (RSV) [41,42] has a significant impact on asthma. In addition, influenza virus, boca-, adeno-, or metapneumoviruses can also cause serious clinical courses in predisposed patients [43-45]. Moreover, HRV and RSV have been proposed to induce secondary diseases, e.g., atopic disorders whose underlying mechanism is not fully understood yet [46-51].

Exacerbation cohorts may provide useful information on pathomolecular interactions, which can be used for the definition of biomarkers [52-54]. However, data from exacerbation cohorts of children with asthma are still scarce [52-54].

Thus, a pediatric exacerbation network, including subjects with chronic recurrent bronchitis or asthma suffering from a respiratory exacerbation/deterioration of the general status were recruited, and nasopharyngeal swab specimens were obtained [52]. For this project, data of the study cohort were stratified based on demographic, clinical, and blood variables [52].

With this project, we aimed to understand the respiratory viriome in connection to microbiome results of exacerbated children. Observations from such a cohort may provide important insights into the acute phase of an asthmatic child for a better understanding of causative molecular aspects.

\section{Materials and Methods}

\subsection{Subject Description and Sample Collection}

Between the years 2017 and 2019, children and adolescents with a history of frequent bronchitis or asthma presenting symptoms of an acute exacerbation were included. Two diseased cohorts were categorized into 'wheezers' and 'asthmatics' [52]. The last subject was enrolled in 2019 before the SARS-CoV-2/COVID-19 pandemic. Therefore, a comparison between virus panel results before and during the pandemic cannot be performed. For the present study, the cohorts were redefined based on distinct clinical and molecular aspects, which will be explained below. In detail, children who were between three months and five years of age with recurrent bronchitis symptoms ('wheezers') and with acute respiratory complaints on the day of presentation at the study center were recruited after obtaining informed consent. According to current asthma guidelines, wheezers cannot be appropriately diagnosed as asthmatics since a lung function test (e.g., spirometry) cannot be performed to confirm the diagnosis appropriately.

Asthmatics who were five to seventeen years old and suffering from an acute exacerbation were also recruited based on the national/international recommendations for the diagnosis of asthma. Acute airway symptoms, including cough, tachy-dyspnea, chest tightness, etc., are included in the Asthma Control Test/GINA (=Global Initiative for Asthma) score (e.g., https:/ / www.asthma.com/understanding-asthma/severe-asthma/asthmacontrol-test/, accessed on 10 December 2021) [52,55,56] and reflect an 'exacerbation' for both diseased cohorts (asthma/wheezers) in this prospective observational trial. Moreover, healthy controls between 3 months to 17 years of age without any acute febrile infection within the last few weeks before study inclusion and without any chronic disorders were also recruited [52].

The stratification of the atopic status was defined according to the following criteria: ImmunoCAP class $\geq 3$, eosinophils, allergic rhino-conjunctivitis, and allergic dermatitis. 
The steroid status was set as positive when a steroid or leukotriene receptor antagonist intake were present within the last months. Moreover, epidemiological and clinical parameters were recorded in order to perform correlation analyses. Among the biomaterials, nasopharyngeal swabs using Copan eSwabs ${ }^{\mathrm{TM}}$ versatile liquid Amies media were deep frozen at $-80{ }^{\circ} \mathrm{C}$ upon collection for further analyses [52,57].

\subsection{FilmArray Respiratory Panel Testing}

For the automated simultaneous detection of different pathogens of the upper respiratory tract (Table 1), the BioFire ${ }^{\circledR}$ FilmArray ${ }^{\circledR}$ Respiratory 2.1 plus panel (Biomerieux) was used according to the manufacturer's recommendations [58].

Table 1. Respiratory virus and bacteria panel for studying the pathogenome of nasopharyngeal swab specimens of the study cohort.

\begin{tabular}{|c|c|c|c|c|c|c|c|}
\hline $\begin{array}{c}\text { AdV } 2 \\
\text { AdV } 3 \\
\text { AdV } 6 \\
\text { AdV } 7.1 \\
\text { AdV } 8\end{array}$ & $\begin{array}{l}\text { CV 229E } \\
\text { CV HKU1 } \\
\text { CV NL63 } \\
\text { CV OC43 }\end{array}$ & $\begin{array}{l}\text { MERS-CoV } \\
\text { SARS-CoV2 }\end{array}$ & HMPV & HRV / HEV & $\begin{array}{l}\text { Influenza A } \\
\text { Influenza B }\end{array}$ & $\begin{array}{l}\text { PIV } 1 \\
\text { PIV } 2 \\
\text { PIV } 3 \\
\text { PIV } 4\end{array}$ & RSV \\
\hline $\begin{array}{l}\text { B. } p . \\
\text { B. pp. }\end{array}$ & C. pneumoniae & M. pneumoniae & & & & & \\
\hline
\end{tabular}

Abbreviations: AdV = adenovirus; CV = coronavirus; MERS-CoV = Middle East respiratory syndrome coronavirus; HMPV = human metapneumovirus; $\mathrm{HRV} / \mathrm{HEV}=$ human rhinovirus/enterovirus; PIV = parainfluenza virus; RSV = respiratory syncytial virus; B. $p .=$ Bordetella pertussis; $B$. pp. = Bordetella parapertussis; C. pneumoniae = Chlamydia pneumoniae; M. pneumoniae $=$ Mycoplasma pneumoniae; SARS-CoV2 = severe acute respiratory syndrome-coronavirus type 2 .

Briefly, approximately $300 \mu \mathrm{L}$ of the raw sample was applied to the FilmArray pouch in an aseptic environment using sterile filter pipet tips. The pouch contains all materials and chemicals required for isolation, purification, amplification, and detection of the targeted nucleic acids. After mechanical lysis and purification using bead beating and magnetic bead technology, respectively, the total nucleic acid extract was applied to a first step multiplex PCR including reverse transcription of targets originating from RNA genomes. Subsequently, a second stage single plex PCR within a multi-well array was performed. To identify targets from positive PCR results, high resolution melting analysis was carried out harnessing the fluorescence emitted by the LCGreen Plus dye, which was captured by a charge-coupled device camera. Finally, the results of the measurement run were processed and presented by the BioFire, FilmArray 2.0, software version 2.1.336.0.

\subsection{Statistical Analyses}

Statistical analyses were performed with R [59] with the packages A Grammar of Data Manipulation (dplyr) [60] and Visualizing Categorical Data (VCD) [61]. Plots were drawn using the ggplot2 package [62]. Categorical data (infection or atopy status) were compared using Fisher's exact test for $2 \times 2$ contingency tables or chi-square independence test for larger contingency tables. In three-dimensional contingency tables, Woolf's test was used to assess if the stratifying variable influenced the odds ratio of the other two parameters. Quantitative data was analyzed using one or two-ways ANOVA tests, or Mann-Whitney U tests in the case of pairwise comparisons. In each analysis involving at least 10 comparisons or correlations, $p$-values were corrected using the FDR method. The significance threshold was set at $p<0.05$.

\section{Results}

\subsection{Patient Characteristics}

Multiplex virus panel testing was performed in a total of 141 study subjects $(n=37$ healthy controls, $n=50$ wheezers, and $n=54$ asthmatics). The mean age of the asthmatics was 9.8 years, 2.1 years in the wheezer group, and 8.2 years in the healthy control groups. The proportion of females in the diseased groups (asthmatics/wheezers) was similar (33.3\% vs. 32.0\%). In 
addition, $76.5 \%$ of asthmatics were atopic; this number was $23.4 \%$ in the wheezer group. Moreover, $42.9 \%$ of the asthmatics had reported a positive steroid intake in the past 12 months, whereas wheezers were steroid positive in $26.5 \%$ of the cases. A detailed presentation of additional clinical parameters is summarized in Table 2.

Table 2. Descriptive summary of patient characteristics.

\begin{tabular}{cccc}
\hline & Asthmatics & Wheezers & Healthy Controls \\
Population $(n)$ & 54 & 50 & 37 \\
Age (years) & $9.8(5.29-17.27)$ & $2.1(0.43-4.48)$ & $8.2(1.39-16.30)$ \\
Female (\%) & 33.3 & 32.0 & 45.9 \\
average (minimum-maximum) & $76.5(n=51)$ & $23.4(n=47)$ & 8.1 \\
Positive atopic status (\%) & $57.1(n=49)$ & $73.5(n=49)$ & 0 \\
Negative steroid status (\%) & $76.7(n=43)$ & $72.9(n=48)$ & $91.2(n=34)$ \\
Breast feeding (\%) & $20.5(n=44)$ & $22.9(n=48)$ & $5.9(n=34)$ \\
Maternal alcohol/tobacco abuse (\%) & $23.3(n=43)$ & $21.3(n=47)$ & $29.4(n=34)$ \\
Pet owner (\%) & $50.0(n=42)$ & $28.3(n=46)$ & $17.7(n=34)$ \\
Mold exposition (\%) & $39.5(n=43)$ & $34.0(n=47)$ & $14.7(n=34)$ \\
Traffic exposition (\%) &
\end{tabular}

\subsection{Rhinovirus and Respiratory Syncytial Virus Are Frequently Associated with} Pediatric Exacerbation

The most frequent viruses within the study population were $\mathrm{HRV} / \mathrm{HEV}(41.1 \%$ of all subjects were infected) and RSV (13.5\%). HRV / HEV was particularly prevalent in the asthmatics group (55.6\%, significant difference with age-matched controls) and RSV in the wheezers group (30\%). Figure 1 shows the distribution of these viruses per group (asthmatics, wheezers, healthy controls $<5$ years, and healthy controls $>5$ years). In total, 13 subjects (9.2\%) suffered from multiple infections by two viruses, 79 (56\%) were infected by a single virus, and 49 (34.8\%) were virus-free.

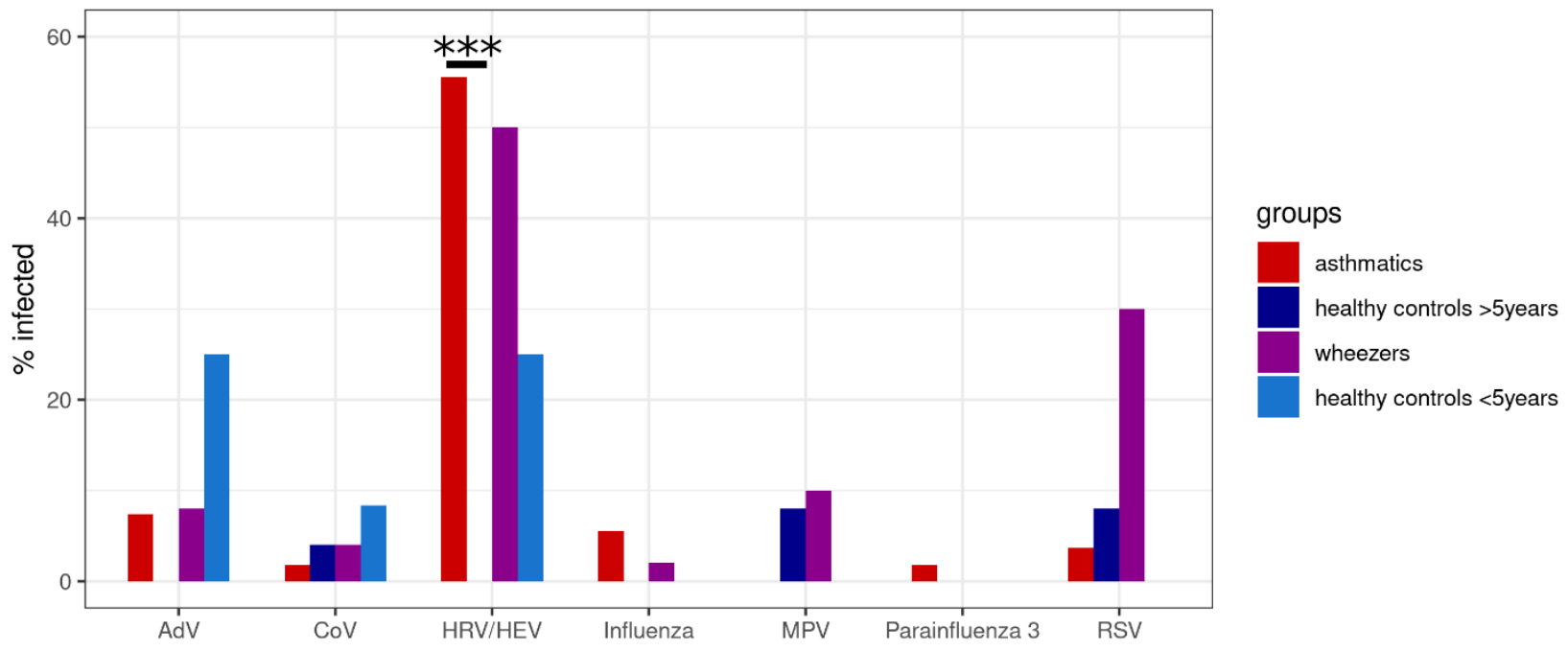

Figure 1. Frequency of infection in different groups. The frequency of infection with each of the studied viruses was compared between asthmatics or wheezers and age-matched controls. Rhinovirus infection levels are significantly higher in asthmatics than in older healthy controls. There is also a substantial difference in RSV infection levels between wheezers and younger controls. The pairwise comparisons were conducted with Fisher's exact test, then the $p$-values were corrected using the FDR method. ${ }^{* * *} p<0.001$. Abbreviations: $\mathrm{AdV}=$ adenovirus, $\mathrm{CoV}=$ coronavirus, $\mathrm{HRV} / \mathrm{HEV}=$ human rhinovirus/human enterovirus, MPV = metapneumovirus, RSV = respiratory syncytial virus). 


\subsection{The Atopy Level Influences the Susceptibility of HRV Infection}

The patient's atopic phenotype may influence the susceptibility to viral infection. We tested this hypothesis in our cohort by detection of HRV/HEV and RSV, the two most prevalent viruses in our cohort. For this, all HRV-infected atopic asthmatics and wheezers were grouped together and compared with those who did not have atopy but were also HRV positive. Interestingly, when all subject groups were combined, atopy was significantly and positively correlated with infectibility $(p=0.000031)$ (Figure 2$)$.
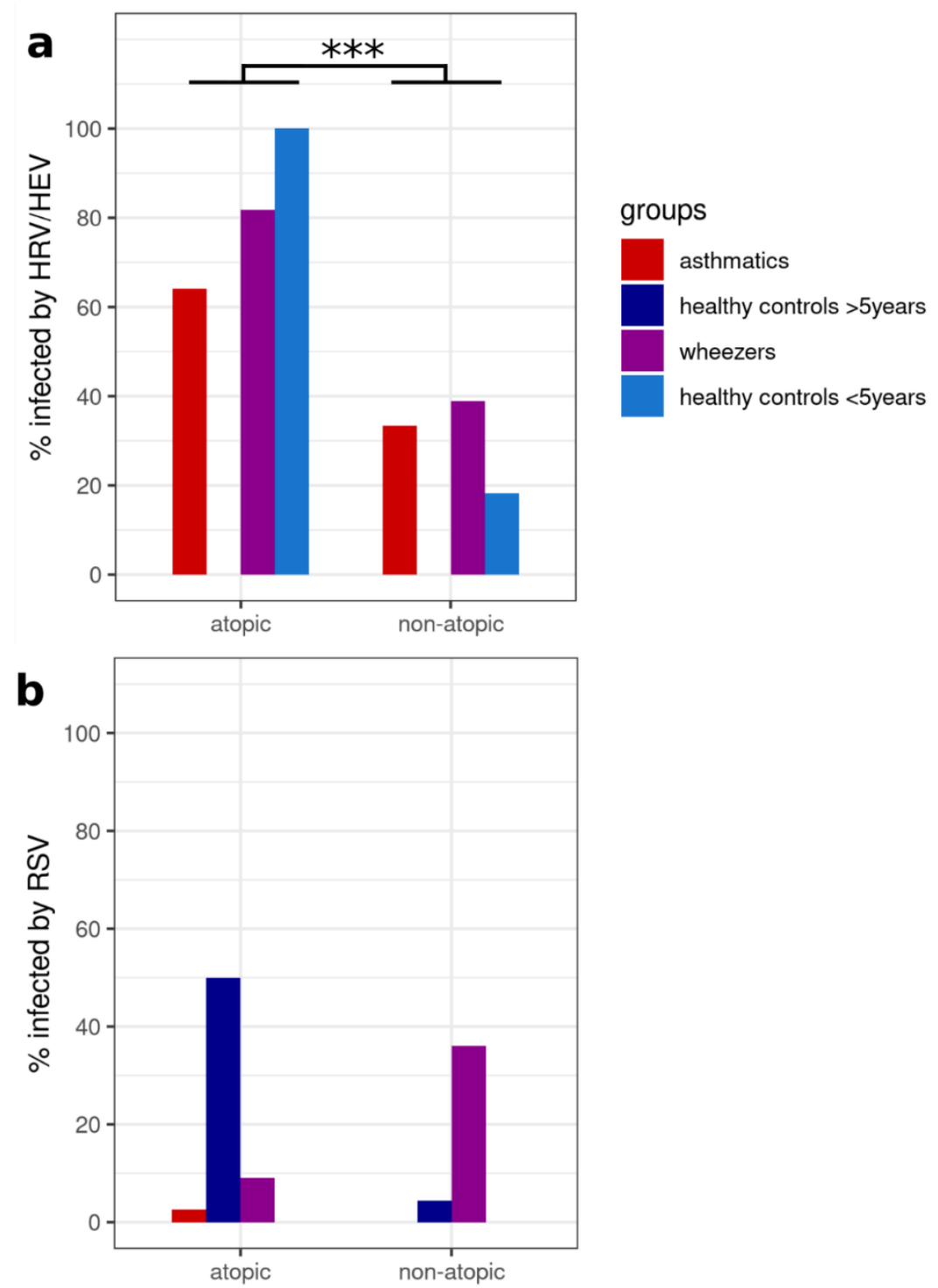

Figure 2. Subjects infected by HRV or by RSV as a function of atopy status. (a) The correlation between infection and atopic status was tested within each group or with all groups combined using Fisher's exact test. Additionally, Woolf tests were conducted to assess if the odds ratio of infection versus atopy status differed between asthmatics and healthy controls older than 5 or between wheezers and healthy controls younger than 5. After all the tests, $p$-values were corrected using the FDR method. Atopy significantly increased HRV infection levels in all groups combined $(p=0.000031)$. (b) There was no significant correlation between atopy status and RSV infection levels. ${ }^{* * *} p<0.001$.

\subsection{Rhinovirus Infection Influences Blood Lymphocyte Levels}

Currently, one of the widest and best characterized endotypes is allergic eosinophilic asthma with type 2 immune response inflammation, which stands for the type 2 T-helper cell lymphocyte (Th2) [30,63]. Chronic lower airway inflammation in asthma is caused by 
infiltration of inflammatory cells, including eosinophils, neutrophils, and T-helper cells, as well as mast cell activation, IgE production triggered by B lymphocytes, and epithelial cell damage $[32,63,64]$. We then analyzed if the group and/or viral infections influenced lymphocytes and eosinophils, which are known to be involved in atopic diseases. Results were either expressed in percentage of total leukocytes or titer per nanoliter. We restricted our analyses to HRV / HEV and RSV, the only two viruses that infected enough subjects to conduct relevant statistical analyses. Finally, we separated our dataset between asthmatics and healthy controls older than five and between wheezers and age-matched controls. Therefore, we conducted a series of 16 2-ways ANOVA tests to assess if the patients group, the viral infection status, or the interaction of both correlated with the selected cell subsets. $p$-values were corrected using the FDR (false discovery rate) multiple comparison correction. The percentage of lymphocytes among leucocytes was significantly correlated with HRV / HEV infection in the younger cohort $(p=0.0014)$ and asthmatic status in the older cohort $\left(p=3.4 \times 10^{-11}\right)$ (Figure 3).

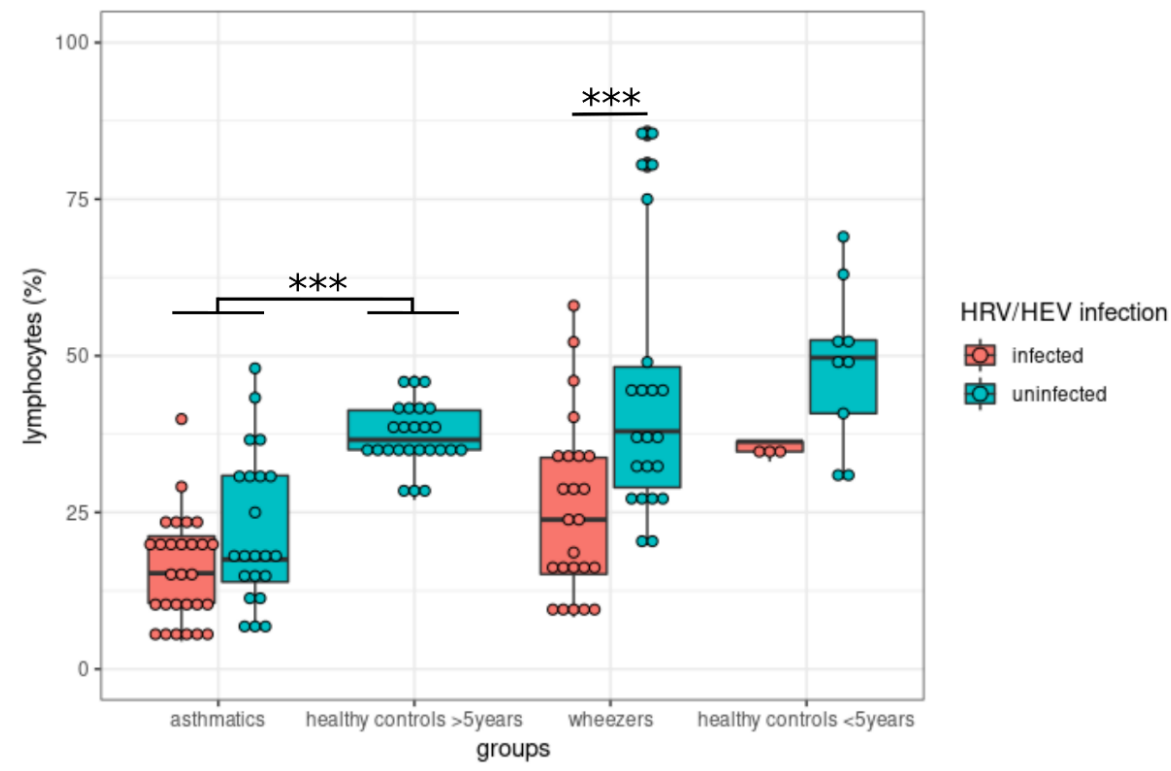

Figure 3. Lymphocytes decreased in HRV/HEV-infected subjects. Post-hoc pairwise comparisons of infected versus non-infected subjects were conducted within each group using the Mann-Whitney $U$, non-parametric test. ${ }^{* * *}=p<0.001$.

Interestingly, the fact that a significant negative correlation was observed when all young children are combined but not within wheezers or within young controls probably indicates that the difference was related to the higher number of infected subjects within the wheezer group. This may be due to both the effects of the groups (wheezers have less lymphocytes) and of HRV infection (infected subjects have less lymphocytes), but more data need to be accumulated to be certain at this level. Furthermore, lymphocyte numbers may vary with age.

\subsection{House Dust Mite Allergy Increases the Susceptibility to Rhinovirus Infection}

Our data and other studies suggest that patients with allergies or atopic diseases have an increased susceptibility to virus infections [65-69]. Therefore, we hypothesized that patients with house dust mite allergies had an increased rate of HRV positive test results. Here, we observed that patients with high serologic levels were at a significantly higher risk of being infected with $\mathrm{HRV} / \mathrm{HEV}$ than those who showed decreased ImmunoCAP values (Figure 4). 


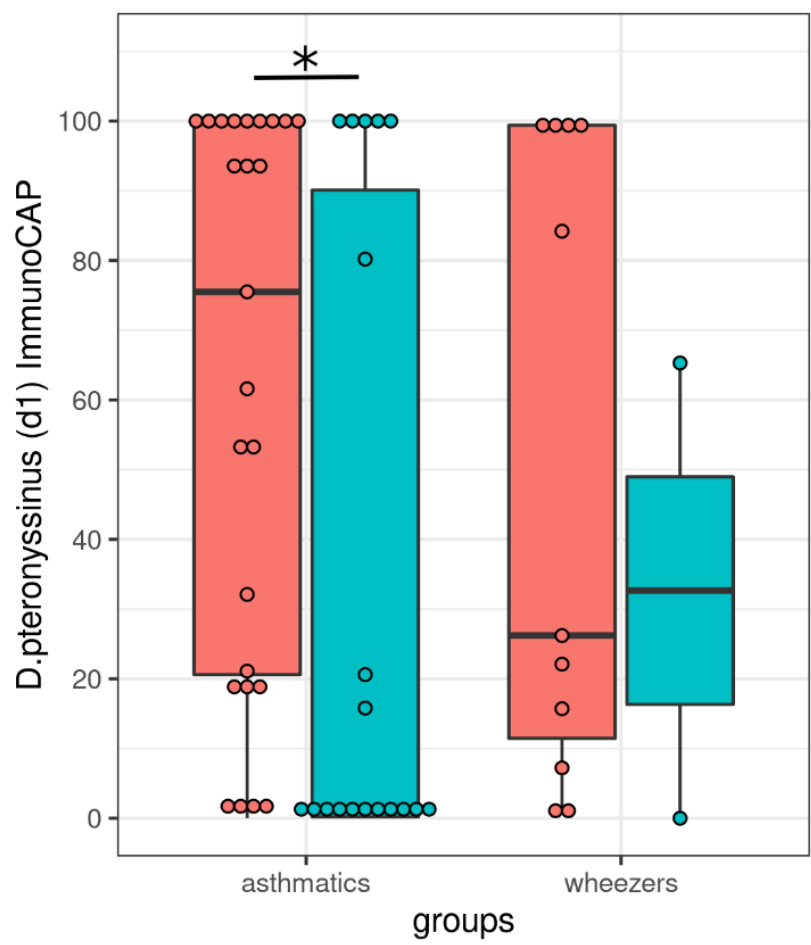

HRV/HEV infection

因 infected

因 uninfected

Figure 4. Patients with house dust mite allergies are susceptible for rhinovirus infection. We hypothesized that dust mite allergy levels, as measured by ImmunoCAP, influence the susceptibility to viral infections. We restricted our analysis to HRV / HEV and RSV and to wheezers and asthmatics since too few healthy controls accepted to undertake ImmunoCAP. For each group and each virus, we conducted a Mann-Whitney $U$ test to assess if the viral infection status correlated with dust mite allergy levels. We found that dust mite allergies increased in HRV / HEV infected asthmatics compared with non-infected asthmatics $(p=0.031) .{ }^{*} p<0.05$.

3.6. The Bacterial Colonization in the Nose or Pharynx Was Not Influenced by Asthma Phenotype among Virus-Infected Subjects

To determine to what extent the microbiome profile interacts with HRV or RSV, we compared our previously published microbiome dataset [57], reanalyzed with the current virus results. We tested for the presence of different bacteria in the pharyngeal and nasal microbiome profiles of our cohort. As also described before, the most frequent bacteria were Haemophilus parainfluenzae, Haemophilus influenzae, Staphylococcus aureus, Streptococcus pneumoniae, and Moraxella catarrhalis [57]. Out of 137 tested subjects, $115(84.4 \%)$ were colonized by at least one bacterium, and 80 (58.4\%) had virus-bacteria coinfections.

We hypothesized that the prevalence of these bacteria may vary between groups in RSV-infected or HRV / HEV-infected patients. However, no significant correlation between group and bacterial infection status was found in any subset of the cohort. We then compared the colonization levels of the selected bacteria in the nose or in the pharynx using the same cohort subsets and detected significant differences in RSV-infected patients $\left(p=1.45 \times 10^{-4}\right), \mathrm{HRV}$-infected patients $\left(p=3.68 \times 10^{-9}\right)$, and HRV-infected atopic patients $\left(p=1.30 \times 10^{-8}\right)($ Figure 5a). Interestingly, pharyngeal Haemophilus (para-)influenza were detected in more patients than all other bacteria and were also more prevalent than nasal Haemophilus (para-)influenza. 

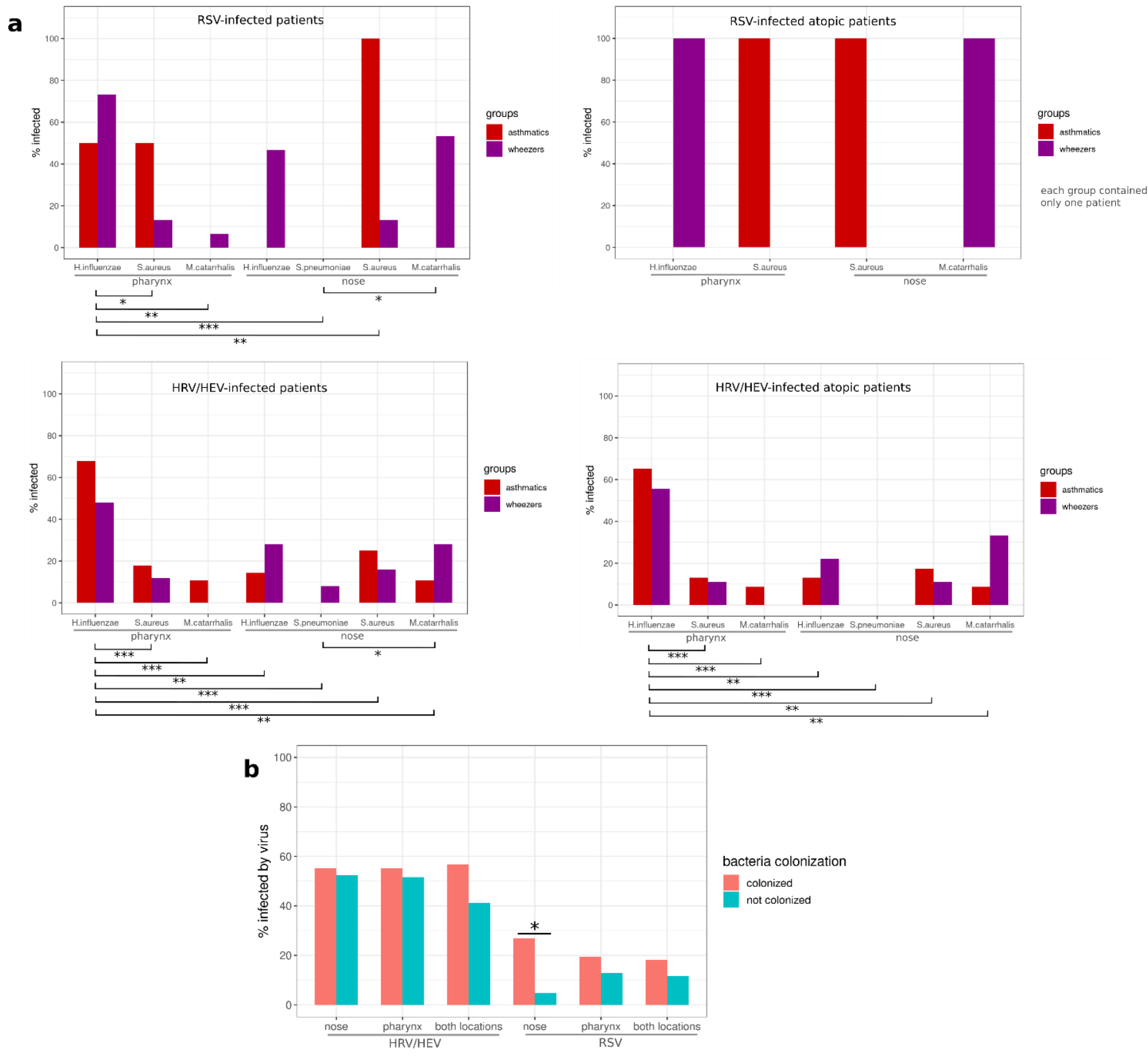

bacteria colonization

colonized

not colonized

Figure 5. Bacterial profiles in patients with human rhinovirus (HRV) or respiratory syncytial virus (RSV) infections (a,b). In each cohort subset, we compared bacteria colonization between groups for each selected bacteria and location and between bacteria and location with all groups combined. We used chi-square tests of independence and corrected all $p$-values using the FDR method. Pairwise comparisons were conducted using Fisher's exact test (Haemophilus influenzae = Haemophilus influenzae + Haemophilus parainfluenzae, S. aureus = Staphylococcus aureus, S. pneumonia = Streptococcus pneumonia, M. catarrhalis = Moraxella catarrhalis). ${ }^{*} p<0.05 ;{ }^{* *} p<0.01 ;{ }^{* *} p<0.001$.

We also asked the question of whether colonization by pathogenic bacteria was associated with HRV/HEV or virus infection. For each of these two viruses, we compared virus infection counts in patients colonized by Haemophilus influenzae/parainfluenzae, Staphylococcus aureus, Streptococcus pneumoniae, or Moraxella catarrhalis in the nose, in the pharynx, or in any of these two locations. We found that RSV infection was significantly increased in subjects with nose colonization ( $p=0.016$, fisher's exact test) (Figure 5). 


\section{Discussion}

Asthma is categorized into different phenotypes and endotypes [70]. Substantial efforts are made to prevent subjects from developing atopic disorders and even predict a severe course or an exacerbation [71-79]. The novel therapeutic alternatives have significantly improved the clinical course of asthma symptoms [80-83]. Beside the allergen aspects as triggering factors for exacerbation, viruses play a major role in seasonal exacerbations, e.g., in winter $[17,55,77,84-87]$. An infection with HRV or RSV may be associated with lifethreatening events and affect disease development and progression [88-95]. Interestingly, in our cohort, HRV and RSV were the most prevalent viruses, which were detected in the nasopharyngeal swab specimens obtained during an exacerbation. It can be proposed that these viruses are the causative pathogens of the current exacerbation.

Due to improved techniques, e.g., multiplex-PCR, it is possible to diagnose examination results rapidly, which enables earlier initiation of therapies [58,96,97]. Such techniques also have the advantage of detecting subgroups of viruses, which can lead to important clues about the corresponding pathomechanism [58]. Indeed, more clinical and experimental information are needed to establish vaccination strategies to counteract the prevalence of atopic diseases. In this project, we were able to detect multiple respiratory viruses and bacteria in the nasopharyngeal swabs of our study population during exacerbation in panel studies, and this data can be utilized for further studies and biomarker development. Such observations are important as they lead to insights into the exacerbation of the diseased child and lay fundamental milestones for further translational projects. In detail, we demonstrated that children with asthma have increased susceptibility to HRV. Our data confirm previous work, and similar studies also present a correlation between HRV and exacerbation $[90,98]$.

HRV, as a single-stranded RNA virus, is an enterovirus and belongs to the picornavirus family, where its capsid has four viral proteins [45,99-102]. It is classified into three species, RV-A, $-\mathrm{B}$, and $-\mathrm{C}$, and it enters the airway epithelial cells through receptor-mediated endocytosis by activating I-CAM 1 (RV-A/-B) and LDLR (RV-A/-B), whereas RV-C binds to the CDHR3 receptor $[99,103,104]$. Upon entering, the genome is recognized by pattern recognition receptors, including Toll-like receptors. Subsequently, distinct immune responses are induced by secreting chemokines and cytokines [99-101,105,106]. Epithelial cells infected with HRV show a predisposition towards bacterial colonization, e.g., Staphylococcus aureus and Streptococcus pneumoniae [99]. Asthmatics infected with HRV have a more severe course than healthy patients, and in concordance with our work, previous studies have already presented that an early infection is a risk factor for children with atopic predispositions (e.g., allergic sensitization, genetic predisposition, etc.) [38,88].

In addition, an early infection with RSV or HRV can cause bronchiolitis and lead to serious damage of the epithelium, which is also associated with an increased risk of developing asthma in later years [17,37,107]. For example, Bergroth and colleagues have shown that children with previous RV-A or RV-C bronchiolitis need to take asthma medications at an early phase and several years after infection [37]. Longitudinal and follow-up analyses of our cohort over several years should indicate whether a previous exacerbation with RSV or HRV may have a negative impact on the course of the subjects.

The respiratory tract harbors not only viruses, but also other microorganisms, such as bacteria and fungi [108-113]. The totality of all microorganisms is called the microbiome, and its pathogenic relevance is still investigated in different molecular and clinical contexts [113-119]. Several studies have already delineated the relationship between the airway microbiome and the pathogenesis of asthma [113,119-123]. Importantly, the first bacterial colonization in humans occurs within $24 \mathrm{~h}$ post-partum and is delayed when the child is delivered by cesarean section $[113,124]$. Due to various external influences, the microbiome changes throughout the life [125]. Viral infections that have passed through may also have an impact on the composition of the microbiome [126]. In our previous work, we observed that the wheezer cohort showed more colonization with distinct bacteria, including Moraxella catarrhalis and Haemophilus (para-)influenzae, whereas asthmatics had an 
increased abundance of Staphylococcus and Streptococcus in the nasopharyngeal swabs [57]. Interestingly, Teo and colleagues showed that patients with a colonization of Streptococcus, Moraxella, and Haemophilus have an increased risk of infection with respiratory viruses, particularly when such patients with the combination of RSV and Moraxella suffered from severe symptoms [127]. Further works also highlighted the high risk of being hospitalized for those patients with a Haemophilus, Moraxella, and Streptococcus colonization and an RSV infection [128].

In addition to RSV, it was demonstrated that HRV also plays a special role in bronchiolitis [88,129]. Furthermore, it was shown that patients with Moraxella colonization have a higher risk of being infected with HRV [130]. For example, Rosas-Salazar and coworkers found that children with HRV and RSV infections were predominantly colonized with Moraxella, Streptococcus, Corynebacterium, Haemophilus, and Dolosigranulum [130].

Considering these studies, our results also support the hypothesis that a colonization with bacteria may be associated with an increased risk of respiratory virus infections. Here, we observed that patients with positive test results of HRV/HEV and RSV infections also had colonizations of distinct bacteria in nasopharyngeal swabs specimens. Therefore, compared to previously published data, the increased detection of HRV and RSV in our cohort provides a good correlation to previous studies. Nevertheless, it is difficult to classify the extent to which the microbiome is a platform for viral infections or whether the microbiome level affects the infectivity, the disease duration, and the severity of respiratory infection in a patient.

Interestingly, patients with high ImmunoCAP values (Dermatophagoides pteryonossinus) were at higher risk of being HRV positive than those with low values. Interestingly, for SARS-CoV-2, there are contradictory results for asthmatics. For example, Yan and colleagues observed that patients with asthma histories suffer from severe SARS-CoV-2 courses. They observed in their Korean cohort that patients with asthma and allergic rhinitis had a serious clinical outcome [69]. Importantly, in the review of Chatziparasidis and Kantar, the authors summarized the fact of why children with asthma may not belong to the high-risk groups in terms of SARS-CoV-2 infections [22]. Indeed, the majority of the patients infected with SARS-CoV-2 were either asymptomatic or had few serious symptoms [22]. Subsequently, Radzikowska et al. analyzed the expression of receptors targeting SARS-CoV-2 in different samples derived from diseased patients (including asthmatics) and healthy controls. They observed that asthmatics had a higher expression of CD147- and ACE2-related genes in different sample types. Whether this or other factors are the reasons for different SARS-CoV2 morbidity will be interesting to investigate in further studies [26].

Finally, it remains to be ascertained as to what extent viral infections affect microbial composition or, conversely, to what extent the microbiome causes an increased susceptibility to viral infection [113]. This pathomechanism is not yet fully understood and will be part of our follow-up work.

\section{Limitations}

As also discussed previously in the study protocol [52], subjects from the western part of Germany were included here while disregarding the aspect of different living conditions, e.g., urban vs. rural. The fact that we recruited a local cohort prevents us from investigating potential external influences on child exacerbation pathomechanisms. Nevertheless, this aspect implies that the cohort is more coherent with less confounding factors, which strengthens our conclusions regarding potential mechanisms [52]. As described previously, due to an improved and updated analysis panel, a specification of HRV and enterovirus is still not possible and a potential cross-reaction with enteroviruses cannot be excluded at this level [58]. Moreover, the longitudinal observational aspect of our subjects over several years is currently missing to address whether children with a history of RSV or HRV infection have had an atopic progression in later years of age. Nonetheless, the recruitment of exacerbated patients is a major hurdle for clinicians and scientists. Thus, this local 
cohort provides important information on the current status of affected children, where the obtained biomaterials are valuable to study experimental questions and to correlate these results with the clinical dataset for the purpose of deciphering important information for potential prevention strategies in clinical settings. Thus, further experimental work should study the impact of HRV subtypes in nasal epithelial cell cultures obtained from patients during exacerbation and the response against the virus in these cultures.

\section{Conclusions}

Asthma is a multifactorial and heterogeneous disease with different phenotypes and endotypes. Several trigger factors are involved during asthma development and exacerbation, and distinct models have already shown the underlying signaling processes. Importantly, viruses are particularly involved, and HRV takes a major part in causing an acute asthma exacerbation. Here, HRV was common in the nasopharyngeal swab specimens of our entire cohort where patients suffered from serious exacerbation event. It would be interesting to study the role of viral infections during the SARS-CoV-2/COVID-19 pandemic and during asthma exacerbation/wheezing. The study inclusion of the last patient was in the year 2019 before the pandemic, so this hypothesis cannot be tested here. Complementary, observational studies in childhood should be performed soon to analyze both seasons. Thus, many efforts need to be invested into the development of vaccination and prevention strategies against HRV to protect asthmatics from such a deteriorated status, which has significant effects on the quality of life.

Author Contributions: Conceptualization, S.W. and M.A.; methodology, F.S., B.G., C.B., E.B., O.M., P.A.-N., A.E. and M.A.; software, E.S. and F.S.; validation, S.W. and M.A.; formal analysis, E.S., F.S., S.W. and M.A.; investigation, S.W.; resources, S.W.; data curation, S.W. and M.A.; writing-original draft preparation, E.S., F.S. and M.A.; writing—review and editing, all authors; visualization, E.S., F.S. and M.A.; supervision, A.E., S.W. and M.A.; project administration, S.W. and M.A.; funding acquisition, S.W. and M.A. All authors have read and agreed to the published version of the manuscript.

Funding: This research received funding from the Internal Research Grant of the Faculty of Health at Witten/Herdecke University, Germany (project numbers: IFF 2019-13, IFF 2020-02). The funding organizations had no role in the design and conduction of the study; sample collection, management, analysis, and interpretation of the data; preparation, review, or approval of the manuscript; or the decision to submit the manuscript for publication.

Institutional Review Board Statement: The study and the analyses were in accordance with the ethical standards and the Helsinki declaration (1964) and its later amendments. The study was approved by the ethics committees of the Witten/Herdecke University, Germany (158/2017) and the Ärztekammer Nordrhein, Düsseldorf, Germany (2019312) and was registered at the German Trials Registry (Deutsches Register für Klinische Studien, DRKS00015738).

Informed Consent Statement: Informed consent was obtained from all subjects and/or their custodians involved in the study.

Data Availability Statement: The data presented in this study are available on request from the corresponding authors.

Acknowledgments: We thank the physicians and nursing colleagues from the Center of Child and Adolescent Medicine, as well as the technicians of the Institute of Medical Laboratory Diagnostics of the Helios University Hospital Wuppertal of the Witten/Herdecke University, Wuppertal, Germany for their excellent qualitative and technical support.

Conflicts of Interest: The authors declare no conflict of interest. The funders had no role in the design of the study; in the collection, analyses, or interpretation of data; in the writing of the manuscript; or in the decision to publish the results. 


\section{References}

1. Ntontsi, P.; Photiades, A.; Zervas, E.; Xanthou, G.; Samitas, K. Genetics and Epigenetics in Asthma. Int. J. Mol. Sci. 2021, $22,2412$. [CrossRef] [PubMed]

2. Vos, T.; Flaxman, A.D.; Naghavi, M.; Lozano, R.; Michaud, C.; Ezzati, M.; Shibuya, K.; Salomon, J.A.; Abdalla, S.; Aboyans, V.; et al. Years lived with disability (YLDs) for 1160 sequelae of 289 diseases and injuries 1990-2010: A systematic analysis for the Global Burden of Disease Study 2010. Lancet 2012, 380, 2163-2196. [CrossRef]

3. Mallol, J.; Crane, J.; von Mutius, E.; Odhiambo, J.; Keil, U.; Stewart, A.; Group, I.P.T.S. The International Study of Asthma and Allergies in Childhood (ISAAC) Phase Three: A global synthesis. Allergol. Immunopathol. 2013, 41, 73-85. [CrossRef] [PubMed]

4. $\quad$ Pearce, N.; Ait-Khaled, N.; Beasley, R.; Mallol, J.; Keil, U.; Mitchell, E.; Robertson, C.; Group, I.P.T.S. Worldwide trends in the prevalence of asthma symptoms: Phase III of the International Study of Asthma and Allergies in Childhood (ISAAC). Thorax 2007, 62, 758-766. [CrossRef] [PubMed]

5. Dharmage, S.C.; Perret, J.L.; Custovic, A. Epidemiology of Asthma in Children and Adults. Front. Pediatr. 2019, 7, 246. [CrossRef]

6. Diseases, G.B.D.; Injuries, C. Global burden of 369 diseases and injuries in 204 countries and territories, 1990-2019: A systematic analysis for the Global Burden of Disease Study 2019. Lancet 2020, 396, 1204-1222. [CrossRef]

7. The Global Asthma Report 2018; Global Asthma Network: Auckland, New Zealand, 2018.

8. Akmatov, M.K.; Holstiege, J.; Steffen, A.; Batzing, J. Trends and regional distribution of outpatient claims for asthma, 2009-2016, Germany. Bull. World Health Organ. 2020, 98, 40-51. [CrossRef]

9. $\quad$ Backer, V.; Harmsen, L.; Lund, T.; Pedersen, L.; Porsbjerg, C.; Rasmussen, L.; Thomsen, S.F.; Nolte, H. A 3-year longitudinal study of asthma quality of life in undiagnosed and diagnosed asthma patients. Int. J. Tuberc. Lung Dis. 2007, 11, 463-469.

10. De Marco, R.; Cerveri, I.; Bugiani, M.; Ferrari, M.; Verlato, G. An undetected burden of asthma in Italy: The relationship between clinical and epidemiological diagnosis of asthma. Eur. Respir. J. 1998, 11, 599-605.

11. Van Gent, R.; van Essen, L.E.; Rovers, M.M.; Kimpen, J.L.; van der Ent, C.K.; de Meer, G. Quality of life in children with undiagnosed and diagnosed asthma. Eur. J. Pediatr. 2007, 166, 843-848. [CrossRef]

12. Wu, A.C.; Greenberger, P.A. Asthma: Overdiagnosed, Underdiagnosed, and Ineffectively Treated. J. Allergy Clin. Immunol. Pract. 2018, 6, 801-802. [CrossRef] [PubMed]

13. Bundesärztekammer (BÄK); Kassenärztliche Bundesvereinigung (KBV). Arbeitsgemein-schaft der Wissenschaftlichen Medizinischen Fachgesellschaften (AWMF). Nationale VersorgungsLeitlinie Asthma-Langfassung. Auflage 2020, 4. [CrossRef]

14. Burbank, A.J.; Sood, A.K.; Kesic, M.J.; Peden, D.B.; Hernandez, M.L. Environmental determinants of allergy and asthma in early life. J. Allergy Clin. Immunol. 2017, 140, 1-12. [CrossRef] [PubMed]

15. Perez, L.; Declercq, C.; Iniguez, C.; Aguilera, I.; Badaloni, C.; Ballester, F.; Bouland, C.; Chanel, O.; Cirarda, F.B.; Forastiere, F.; et al. Chronic burden of near-roadway traffic pollution in 10 European cities (APHEKOM network). Eur. Respir. J. 2013, 42, 594-605. [CrossRef] [PubMed]

16. Busse, W.W.; Lemanske, R.F., Jr.; Gern, J.E. Role of viral respiratory infections in asthma and asthma exacerbations. Lancet 2010, 376, 826-834. [CrossRef]

17. Jartti, T.; Gern, J.E. Role of viral infections in the development and exacerbation of asthma in children. J. Allergy Clin. Immunol. 2017, 140, 895-906. [CrossRef]

18. Ko, F.W.; Chan, P.K.; Chan, R.W.Y.; Chan, K.P.; Ip, A.; Kwok, A.; Ngai, J.C.; Ng, S.S.; On, C.T.; Hui, D.S. Molecular detection of respiratory pathogens and typing of human rhinovirus of adults hospitalized for exacerbation of asthma and chronic obstructive pulmonary disease. Respir. Res. 2019, 20, 210. [CrossRef]

19. Merckx, J.; Ducharme, F.M.; Martineau, C.; Zemek, R.; Gravel, J.; Chalut, D.; Poonai, N.; Quach, C.; Pediatric Emergency Research Canada, D.T. Respiratory Viruses and Treatment Failure in Children with Asthma Exacerbation. Pediatrics 2018, 142. [CrossRef]

20. Zheng, S.Y.; Wang, L.L.; Ren, L.; Luo, J.; Liao, W.; Liu, E.M. Epidemiological analysis and follow-up of human rhinovirus infection in children with asthma exacerbation. J. Med. Virol. 2018, 90, 219-228. [CrossRef]

21. Borchers, A.T.; Chang, C.; Gershwin, M.E.; Gershwin, L.J. Respiratory syncytial virus-A comprehensive review. Clin. Rev. Allergy Immunol. 2013, 45, 331-379. [CrossRef]

22. Chatziparasidis, G.; Kantar, A. COVID-19 in Children with Asthma. Lung 2021, 199, 7-12. [CrossRef] [PubMed]

23. Chow, E.J.; Doyle, J.D.; Uyeki, T.M. Influenza virus-related critical illness: Prevention, diagnosis, treatment. Crit. Care 2019, $23,214$. [CrossRef] [PubMed]

24. Kumar, K.; Singanayagam, A.; Johnston, S.L. Respiratory Virus Infections in Asthma: Research Developments and Therapeutic Advances. Acta. Med. Acad. 2020, 49, 130-143. [CrossRef] [PubMed]

25. Obuchi, M.; Adachi, Y.; Takizawa, T.; Sata, T. Influenza A(H1N1)pdm09 virus and asthma. Front. Microbiol. 2013, 4, 307. [CrossRef]

26. Radzikowska, U.; Ding, M.; Tan, G.; Zhakparov, D.; Peng, Y.; Wawrzyniak, P.; Wang, M.; Li, S.; Morita, H.; Altunbulakli, C.; et al. Distribution of ACE2, CD147, CD26, and other SARS-CoV-2 associated molecules in tissues and immune cells in health and in asthma, COPD, obesity, hypertension, and COVID-19 risk factors. Allergy 2020, 75, 2829-2845. [CrossRef]

27. Sienko, J.; Kotowski, M.; Bogacz, A.; Lechowicz, K.; Drozdzal, S.; Rosik, J.; Sietnicki, M.; Sienko, M.; Kotfis, K. COVID-19: The Influence of ACE Genotype and ACE-I and ARBs on the Course of SARS-CoV-2 Infection in Elderly Patients. Clin. Interv. Aging 2020, 15, 1231-1240. [CrossRef]

28. Tay, H.; Wark, P.A.; Bartlett, N.W. Advances in the treatment of virus-induced asthma. Expert Rev. Respir. Med. 2016, 10, 629-641. [CrossRef] 
29. Cipriani, F.; Calamelli, E.; Ricci, G. Allergen Avoidance in Allergic Asthma. Front. Pediatr 2017, 5, 103. [CrossRef]

30. Guibas, G.V.; Mathioudakis, A.G.; Tsoumani, M.; Tsabouri, S. Relationship of Allergy with Asthma: There Are More Than the Allergy "Eggs" in the Asthma "Basket". Front. Pediatr. 2017, 5, 92. [CrossRef]

31. Hashmi, M.F.; Tariq, M.; Cataletto, M.E. Asthma. In StatPearls; StatPearls: Treasure Island, FL, USA, 2022.

32. Locksley, R.M. Asthma and allergic inflammation. Cell 2010, 140, 777-783. [CrossRef]

33. Quirt, J.; Hildebrand, K.J.; Mazza, J.; Noya, F.; Kim, H. Asthma. Allergy Asthma Clin. Immunol. 2018, 14, 50. [CrossRef] [PubMed]

34. Finotto, S. Resolution of allergic asthma. Semin Immunopathol. 2019, 41, 665-674. [CrossRef] [PubMed]

35. Tesch, F.; Sydendal Grand, T.; Wuestenberg, E.; Elliott, L.; Schmitt, J.; Kuster, D. Healthcare costs associated with allergic rhinitis, asthma allergy immunotherapy. Eur Ann. Allergy Clin. Immunol. 2020, 52, 164-174. [CrossRef] [PubMed]

36. Hsu, J.; Qin, X.; Beavers, S.F.; Mirabelli, M.C. Asthma-Related School Absenteeism, Morbidity, and Modifiable Factors. Am. J. Prev. Med. 2016, 51, 23-32. [CrossRef] [PubMed]

37. Bergroth, E.; Aakula, M.; Elenius, V.; Remes, S.; Piippo-Savolainen, E.; Korppi, M.; Piedra, P.A.; Bochkov, Y.A.; Gern, J.E.; Camargo, C.A., Jr.; et al. Rhinovirus Type in Severe Bronchiolitis and the Development of Asthma. J. Allergy Clin. Immunol. Pract. 2020, 8, 588-595.e584. [CrossRef] [PubMed]

38. Liu, L.; Pan, Y.; Zhu, Y.; Song, Y.; Su, X.; Yang, L.; Li, M. Association between rhinovirus wheezing illness and the development of childhood asthma: A meta-analysis. BMJ Open 2017, 7, e013034. [CrossRef]

39. Muehling, L.M.; Heymann, P.W.; Wright, P.W.; Eccles, J.D.; Agrawal, R.; Carper, H.T.; Murphy, D.D.; Workman, L.J.; Word, C.R.; Ratcliffe, S.J.; et al. Human TH1 and TH2 cells targeting rhinovirus and allergen coordinately promote allergic asthma. J. Allergy Clin. Immunol. 2020, 146, 555-570. [CrossRef]

40. Williams, T.C.; Jackson, D.J.; Maltby, S.; Walton, R.P.; Ching, Y.M.; Glanville, N.; Singanayagam, A.; Brewins, J.J.; Clarke, D.; Hirsman, A.G.; et al. Rhinovirus-induced CCL17 and CCL22 in Asthma Exacerbations and Differential Regulation by STAT6. Am. J. Respir Cell Mol. Biol. 2021, 64, 344-356. [CrossRef]

41. Coutts, J.; Fullarton, J.; Morris, C.; Grubb, E.; Buchan, S.; Rodgers-Gray, B.; Thwaites, R. Association between respiratory syncytial virus hospitalization in infancy and childhood asthma. Pediatr. Pulmonol. 2020, 55, 1104-1110. [CrossRef]

42. Ruotsalainen, M.; Hyvarinen, M.K.; Piippo-Savolainen, E.; Korppi, M. Adolescent asthma after rhinovirus and respiratory syncytial virus bronchiolitis. Pediatr. Pulmonol. 2013, 48, 633-639. [CrossRef]

43. Coverstone, A.M.; Wang, L.; Sumino, K. Beyond Respiratory Syncytial Virus and Rhinovirus in the Pathogenesis and Exacerbation of Asthma: The Role of Metapneumovirus, Bocavirus and Influenza Virus. Immunol. Allergy Clin. N. Am. 2019, 39, 391-401. [CrossRef] [PubMed]

44. Garcia-Garcia, M.L.; Calvo Rey, C.; Del Rosal Rabes, T. Pediatric Asthma and Viral Infection. Arch. Bronconeumol. 2016, 52, 269-273. [CrossRef]

45. Jartti, T.; Bonnelykke, K.; Elenius, V.; Feleszko, W. Role of viruses in asthma. Semin. Immunopathol. 2020, 42, 61-74. [CrossRef] [PubMed]

46. Guilbert, T.W.; Singh, A.M.; Danov, Z.; Evans, M.D.; Jackson, D.J.; Burton, R.; Roberg, K.A.; Anderson, E.L.; Pappas, T.E.; Gangnon, R.; et al. Decreased lung function after preschool wheezing rhinovirus illnesses in children at risk to develop asthma J. Allergy Clin. Immunol. 2011, 128, 532-538.e10. [CrossRef]

47. Jackson, D.J.; Gangnon, R.E.; Evans, M.D.; Roberg, K.A.; Anderson, E.L.; Pappas, T.E.; Printz, M.C.; Lee, W.M.; Shult, P.A.; Reisdorf, E.; et al. Wheezing rhinovirus illnesses in early life predict asthma development in high-risk children. Am. J. Respir. Crit. Care Med. 2008, 178, 667-672. [CrossRef] [PubMed]

48. Rubner, F.J.; Jackson, D.J.; Evans, M.D.; Gangnon, R.E.; Tisler, C.J.; Pappas, T.E.; Gern, J.E.; Lemanske, R.F., Jr. Early life rhinovirus wheezing, allergic sensitization, and asthma risk at adolescence. J. Allergy Clin. Immunol. 2017, 139, 501-507. [CrossRef] [PubMed]

49. Sigurs, N.; Bjarnason, R.; Sigurbergsson, F.; Kjellman, B. Respiratory syncytial virus bronchiolitis in infancy is an important risk factor for asthma and allergy at age 7. Am. J. Respir. Crit. Care Med. 2000, 161, 1501-1507. [CrossRef]

50. Sigurs, N.; Bjarnason, R.; Sigurbergsson, F.; Kjellman, B.; Bjorksten, B. Asthma and immunoglobulin E antibodies after respiratory syncytial virus bronchiolitis: A prospective cohort study with matched controls. Pediatrics 1995, 95, 500-505. [CrossRef]

51. Sigurs, N.; Gustafsson, P.M.; Bjarnason, R.; Lundberg, F.; Schmidt, S.; Sigurbergsson, F.; Kjellman, B. Severe respiratory syncytial virus bronchiolitis in infancy and asthma and allergy at age 13. Am. J. Respir. Crit. Care Med. 2005, 171, 137-141. [CrossRef]

52. Aydin, M.; Naumova, E.A.; Lutz, S.; Meyer-Bahlburg, A.; Arnold, W.H.; Kreppel, F.; Ehrhardt, A.; Postberg, J.; Wirth, S. Do Current Asthma-Preventive Measures Appropriately Face the World Health Organization's Concerns: A Study Presentation of a New Clinical, Prospective, Multicentric Pediatric Asthma Exacerbation Cohort in Germany. Front. Pediatr. 2020, 8, 574462. [CrossRef]

53. Engelkes, M.; Baan, E.J.; de Ridder, M.A.J.; Svensson, E.; Prieto-Alhambra, D.; Lapi, F.; Giaquinto, C.; Picelli, G.; Boudiaf, N.; Albers, F.; et al. Incidence, risk factors and re-exacerbation rate of severe asthma exacerbations in a multinational, multidatabase pediatric cohort study. Pediatr. Allergy Immunol. 2020, 31, 496-505. [CrossRef] [PubMed]

54. Nasreen, S.; Wilk, P.; Mullowney, T.; Karp, I. Asthma exacerbation trajectories and their predictors in children with incident asthma. Ann. Allergy Asthma Immunol. 2019, 123, 293-300.e292. [CrossRef] [PubMed]

55. Global Initiative for Asthma. Global Strategy for Asthma Management and Prevention. 2021. Available online: www.ginasthma. org (accessed on 10 December 2021). 
56. Thomas, M.; Kay, S.; Pike, J.; Williams, A.; Rosenzweig, J.R.; Hillyer, E.V.; Price, D. The Asthma Control Test (ACT) as a predictor of GINA guideline-defined asthma control: Analysis of a multinational cross-sectional survey. Prim. Care Respir. J. 2009, 18, 41-49. [CrossRef]

57. Aydin, M.; Weisser, C.; Rué, O.; Mariadassou, M.; Maaß, S.; Behrendt, A.-K.; Jaszczyszyn, Y.; Heilker, T.; Spaeth, M.; Vogel, S.; et al. The Rhinobiome of Exacerbated Wheezers and Asthmatics: Insights From a German Pediatric Exacerbation Network. Front. Allergy 2021, 2, 667562. [CrossRef]

58. Leber, A.L.; Everhart, K.; Daly, J.A.; Hopper, A.; Harrington, A.; Schreckenberger, P.; McKinley, K.; Jones, M.; Holmberg, K.; Kensinger, B. Multicenter Evaluation of BioFire FilmArray Respiratory Panel 2 for Detection of Viruses and Bacteria in Nasopharyngeal Swab Samples. J. Clin. Microbiol 2018, 56, e01945-17. [CrossRef]

59. R Core Team. R: A Language and Environment for Statistical Computing; R Foundation for Statistical Computing: Vienna, Austria, 2020.

60. Hadley, W.; François, R.; Henry, L.; Müller, K. dplyr: A Grammar of Data Manipulation. R Package Version 1.0.7; 2021.

61. David Meyer, A.Z.; Hornik, K. vcd: Visualizing Categorical Data. R Package Version 1.4-9; 2021.

62. Wickham, H. ggplot2: Elegant Graphics for Data Analysis; Springer: New York, NY, USA, 2016.

63. Komlosi, Z.I.; van de Veen, W.; Kovacs, N.; Szucs, G.; Sokolowska, M.; O’Mahony, L.; Akdis, M.; Akdis, C.A. Cellular and molecular mechanisms of allergic asthma. Mol. Aspects Med. 2021, 100995. [CrossRef]

64. Mims, J.W. Asthma: Definitions and pathophysiology. Int. Forum Allergy Rhinol. 2015, 5, S2-S6. [CrossRef]

65. Holt, P.G. Developmental factors as determinants of risk for infections and atopy in childhood. Eur. Respir. Rev. 2005, 14, 69-73. [CrossRef]

66. Martinez, F.D. Heterogeneity of the association between lower respiratory illness in infancy and subsequent asthma. Proc. Am. Thorac Soc. 2005, 2, 157-161. [CrossRef]

67. Nicholas, B.; Dudley, S.; Tariq, K.; Howarth, P.; Lunn, K.; Pink, S.; Sterk, P.J.; Adcock, I.M.; Monk, P.; Djukanovic, R.; et al. Susceptibility to influenza virus infection of bronchial biopsies in asthma. J. Allergy Clin. Immunol. 2017, 140, 309-312.e304. [CrossRef]

68. Van Kerkhove, M.D.; Vandemaele, K.A.; Shinde, V.; Jaramillo-Gutierrez, G.; Koukounari, A.; Donnelly, C.A.; Carlino, L.O.; Owen, R.; Paterson, B.; Pelletier, L.; et al. Risk factors for severe outcomes following 2009 influenza A (H1N1) infection: A global pooled analysis. PLoS Med. 2011, 8, e1001053. [CrossRef] [PubMed]

69. Yang, J.M.; Koh, H.Y.; Moon, S.Y.; Yoo, I.K.; Ha, E.K.; You, S.; Kim, S.Y.; Yon, D.K.; Lee, S.W. Allergic disorders and susceptibility to and severity of COVID-19: A nationwide cohort study. J. Allergy Clin. Immunol. 2020, 146, 790-798. [CrossRef] [PubMed]

70. Kuruvilla, M.E.; Lee, F.E.; Lee, G.B. Understanding Asthma Phenotypes, Endotypes, and Mechanisms of Disease. Clin. Rev. Allergy Immunol. 2019, 56, 219-233. [CrossRef]

71. Cabana, M.D.; McKean, M.; Caughey, A.B.; Fong, L.; Lynch, S.; Wong, A.; Leong, R.; Boushey, H.A.; Hilton, J.F. Early Probiotic Supplementation for Eczema and Asthma Prevention: A Randomized Controlled Trial. Pediatrics 2017, 140. [CrossRef] [PubMed]

72. Forno, E.; Bacharier, L.B.; Phipatanakul, W.; Guilbert, T.W.; Cabana, M.D.; Ross, K.; Covar, R.; Gern, J.E.; Rosser, F.J.; Blatter, J.; et al Effect of Vitamin D3 Supplementation on Severe Asthma Exacerbations in Children with Asthma and Low Vitamin D Levels: The VDKA Randomized Clinical Trial. JAMA 2020, 324, 752-760. [CrossRef]

73. Greer, F.R.; Sicherer, S.H.; Burks, A.W.; Committee on Nutrition; Section on Allergy and Immunology. The Effects of Early Nutritional Interventions on the Development of Atopic Disease in Infants and Children: The Role of Maternal Dietary Restriction, Breastfeeding, Hydrolyzed Formulas, and Timing of Introduction of Allergenic Complementary Foods. Pediatrics 2019, 143, e20190281. [CrossRef]

74. Guilbert, T.W.; Morgan, W.J.; Krawiec, M.; Lemanske, R.F., Jr.; Sorkness, C.; Szefler, S.J.; Larsen, G.; Spahn, J.D.; Zeiger, R.S.; Heldt, G.; et al. The Prevention of Early Asthma in Kids study: Design, rationale and methods for the Childhood Asthma Research and Education network. Control Clin. Trials 2004, 25, 286-310. [CrossRef]

75. Mastrorilli, C.; Caffarelli, C.; Hoffmann-Sommergruber, K. Food allergy and atopic dermatitis: Prediction, progression, and prevention. Pediatr. Allergy Immunol. 2017, 28, 831-840. [CrossRef]

76. Menzies-Gow, A.; Busse, W.W.; Castro, M.; Jackson, D.J. Prevention and Treatment of Asthma Exacerbations in Adults. J. Allergy Clin. Immunol. Pract. 2021, 9, 2578-2586. [CrossRef]

77. Murray, C.S.; Foden, P.; Sumner, H.; Shepley, E.; Custovic, A.; Simpson, A. Preventing Severe Asthma Exacerbations in Children A Randomized Trial of Mite-Impermeable Bedcovers. Am. J. Respir. Crit. Care Med. 2017, 196, 150-158. [CrossRef]

78. Nicholson, P.J.; Cullinan, P.; Burge, S.; British Occupational Health Research, F. Concise guidance: Diagnosis, management and prevention of occupational asthma. Clin. Med. 2012, 12, 156-159. [CrossRef] [PubMed]

79. Tachimoto, H.; Imanari, E.; Mezawa, H.; Okuyama, M.; Urashima, T.; Hirano, D.; Gocho, N.; Urashima, M. Effect of Avoiding Cow's Milk Formula at Birth on Prevention of Asthma or Recurrent Wheeze Among Young Children: Extended Follow-up from the ABC Randomized Clinical Trial. JAMA Netw Open 2020, 3, e2018534. [CrossRef] [PubMed]

80. Agache, I.; Beltran, J.; Akdis, C.; Akdis, M.; Canelo-Aybar, C.; Canonica, G.W.; Casale, T.; Chivato, T.; Corren, J.; Del Giacco, S.; et al Efficacy and safety of treatment with biologicals (benralizumab, dupilumab, mepolizumab, omalizumab and reslizumab) for severe eosinophilic asthma. A systematic review for the EAACI Guidelines-Recommendations on the use of biologicals in severe asthma. Allergy 2020, 75, 1023-1042. [CrossRef] [PubMed] 
81. Chapman, K.R.; Albers, F.C.; Chipps, B.; Munoz, X.; Devouassoux, G.; Bergna, M.; Galkin, D.; Azmi, J.; Mouneimne, D.; Price, R.G.; et al. The clinical benefit of mepolizumab replacing omalizumab in uncontrolled severe eosinophilic asthma. Allergy 2019, 74, 1716-1726. [CrossRef]

82. Ortega, H.G.; Liu, M.C.; Pavord, I.D.; Brusselle, G.G.; FitzGerald, J.M.; Chetta, A.; Humbert, M.; Katz, L.E.; Keene, O.N.; Yancey, S.W.; et al. Mepolizumab treatment in patients with severe eosinophilic asthma. N. Engl. J. Med. 2014, 371, $1198-1207$. [CrossRef]

83. Soong, W.; Yoo, B.; Pazwash, H.; Holweg, C.T.J.; Casale, T.B. Omalizumab response in patients with asthma by number and type of allergen. Ann. Allergy Asthma Immunol. 2021, 127, 223-231. [CrossRef]

84. Chau-Etchepare, F.; Hoerger, J.L.; Kuhn, B.T.; Zeki, A.A.; Haczku, A.; Louie, S.; Kenyon, N.J.; Davis, C.E.; Schivo, M. Viruses and non-allergen environmental triggers in asthma. J. Investig. Med. 2019, 67, 1029-1041. [CrossRef]

85. Costa, L.D.; Costa, P.S.; Camargos, P.A. Exacerbation of asthma and airway infection: Is the virus the villain? J. Pediatr. 2014, 90, 542-555. [CrossRef]

86. Deschildre, A.; Pichavant, M.; Engelmann, I.; Langlois, C.; Drumez, E.; Pouessel, G.; Boileau, S.; Romero-Cubero, D.; DecleyreBadiu, I.; Dewilde, A.; et al. Virus-triggered exacerbation in allergic asthmatic children: Neutrophilic airway inflammation and alteration of virus sensors characterize a subgroup of patients. Respir. Res. 2017, 18, 191. [CrossRef]

87. Zhu, J.; Message, S.D.; Mallia, P.; Kebadze, T.; Contoli, M.; Ward, C.K.; Barnathan, E.S.; Mascelli, M.A.; Kon, O.M.; Papi, A.; et al Bronchial mucosal IFN-alpha/beta and pattern recognition receptor expression in patients with experimental rhinovirus-induced asthma exacerbations. J. Allergy Clin. Immunol. 2019, 143, 114-125.e114. [CrossRef]

88. Biagi, C.; Rocca, A.; Poletti, G.; Fabi, M.; Lanari, M. Rhinovirus Infection in Children with Acute Bronchiolitis and Its Impact on Recurrent Wheezing and Asthma Development. Microorganisms 2020, 8, 1620. [CrossRef] [PubMed]

89. Ferolla, F.M.; Hijano, D.R.; Acosta, P.L.; Rodriguez, A.; Duenas, K.; Sancilio, A.; Barboza, E.; Caria, A.; Gago, G.F.; Almeida, R.E.; et al. Macronutrients during pregnancy and life-threatening respiratory syncytial virus infections in children. Am. J. Respir. Crit. Care Med. 2013, 187, 983-990. [CrossRef] [PubMed]

90. Kennedy, J.L.; Pham, S.; Borish, L. Rhinovirus and Asthma Exacerbations. Immunol. Allergy Clin. N. Am. 2019, 39, 335-344. [CrossRef] [PubMed]

91. Niespodziana, K.; Stenberg-Hammar, K.; Megremis, S.; Cabauatan, C.R.; Napora-Wijata, K.; Vacal, P.C.; Gallerano, D.; Lupinek, C.; Ebner, D.; Schlederer, T.; et al. PreDicta chip-based high resolution diagnosis of rhinovirus-induced wheeze. Nat. Commun. 2018, 9, 2382. [CrossRef]

92. Real-Hohn, A.; Blaas, D. Rhinovirus Inhibitors: Including a New Target, the Viral RNA. Viruses 2021, 13, 1784. [CrossRef]

93. Tang, J.W.; Loh, T.P. Correlations between climate factors and incidence-a contributor to RSV seasonality. Rev. Med. Virol. 2014, 24, 15-34. [CrossRef]

94. Teeratakulpisarn, J.; Pientong, C.; Ekalaksananan, T.; Ruangsiripiyakul, H.; Uppala, R. Rhinovirus infection in children hospitalized with acute bronchiolitis and its impact on subsequent wheezing or asthma: A comparison of etiologies. Asian Pac. J. Allergy Immunol. 2014, 32, 226-234. [CrossRef]

95. Zhou, Y.; Tong, L.; Li, M.; Wang, Y.; Li, L.; Yang, D.; Zhang, Y.; Chen, Z. Recurrent Wheezing and Asthma After Respiratory Syncytial Virus Bronchiolitis. Front. Pediatr. 2021, 9, 649003. [CrossRef]

96. Elnifro, E.M.; Ashshi, A.M.; Cooper, R.J.; Klapper, P.E. Multiplex PCR: Optimization and application in diagnostic virology. Clin. Microbiol. Rev. 2000, 13, 559-570. [CrossRef]

97. Vila, J.; Gomez, M.D.; Salavert, M.; Bosch, J. [Methods of rapid diagnosis in clinical microbiology: Clinical needs]. Enferm. Infecc. Microbiol. Clin. 2017, 35, 41-46. [CrossRef]

98. De Kluijver, J.; Evertse, C.E.; Sont, J.K.; Schrumpf, J.A.; van Zeijl-van der Ham, C.J.; Dick, C.R.; Rabe, K.F.; Hiemstra, P.S.; Sterk, P.J. Are rhinovirus-induced airway responses in asthma aggravated by chronic allergen exposure? Am. J. Respir. Crit. Care Med. 2003, 168, 1174-1180. [CrossRef]

99. Yang, Z.; Mitlander, H.; Vuorinen, T.; Finotto, S. Mechanism of Rhinovirus Immunity and Asthma. Front. Immunol. 2021, 12, 731846. [CrossRef] [PubMed]

100. Jacobs, S.E.; Lamson, D.M.; St George, K.; Walsh, T.J. Human rhinoviruses. Clin. Microbiol. Rev. 2013, 26, 135-162. [CrossRef] [PubMed]

101. Kerr, S.L.; Mathew, C.; Ghildyal, R. Rhinovirus and Cell Death. Viruses 2021, 13, 629. [CrossRef] [PubMed]

102. Rossmann, M.G.; Arnold, E.; Erickson, J.W.; Frankenberger, E.A.; Griffith, J.P.; Hecht, H.J.; Johnson, J.E.; Kamer, G.; Luo, M.; Mosser, A.G.; et al. Structure of a human common cold virus and functional relationship to other picornaviruses. Nature 1985, 317, 145-153. [CrossRef]

103. Basnet, S.; Palmenberg, A.C.; Gern, J.E. Rhinoviruses and Their Receptors. Chest 2019, 155, 1018-1025. [CrossRef]

104. Schober, D.; Kronenberger, P.; Prchla, E.; Blaas, D.; Fuchs, R. Major and minor receptor group human rhinoviruses penetrate from endosomes by different mechanisms. J. Virol. 1998, 72, 1354-1364. [CrossRef]

105. Hewson, C.A.; Jardine, A.; Edwards, M.R.; Laza-Stanca, V.; Johnston, S.L. Toll-like receptor 3 is induced by and mediates antiviral activity against rhinovirus infection of human bronchial epithelial cells. J. Virol. 2005, 79, 12273-12279. [CrossRef]

106. Triantafilou, K.; Vakakis, E.; Richer, E.A.; Evans, G.L.; Villiers, J.P.; Triantafilou, M. Human rhinovirus recognition in non-immune cells is mediated by Toll-like receptors and MDA-5, which trigger a synergetic pro-inflammatory immune response. Virulence 2011, 2, 22-29. [CrossRef] 
107. Hasegawa, K.; Mansbach, J.M.; Camargo, C.A., Jr. Infectious pathogens and bronchiolitis outcomes. Expert Rev. Anti-Infect. Ther. 2014, 12, 817-828. [CrossRef]

108. Bakaletz, L.O. Viral-bacterial co-infections in the respiratory tract. Curr. Opin. Microbiol. 2017, 35, 30-35. [CrossRef] [PubMed]

109. Lednicky, J.A.; Rayner, J.O. Uncommon respiratory pathogens. Curr. Opin. Pulm. Med. 2006, 12, 235-239. [CrossRef] [PubMed]

110. Man, W.H.; de Steenhuijsen Piters, W.A.; Bogaert, D. The microbiota of the respiratory tract: Gatekeeper to respiratory health. Nat. Rev. Microbiol. 2017, 15, 259-270. [CrossRef]

111. Pendleton, K.M.; Huffnagle, G.B.; Dickson, R.P. The significance of Candida in the human respiratory tract: Our evolving understanding. Pathog. Dis. 2017, 75, ftx029. [CrossRef] [PubMed]

112. Reckziegel, M.; Weber-Osel, C.; Egerer, R.; Gruhn, B.; Kubek, F.; Walther, M.; Wilhelm, S.; Zell, R.; Krumbholz, A. Viruses and atypical bacteria in the respiratory tract of immunocompromised and immunocompetent patients with airway infection. Eur $J$. Clin. Microbiol. Infect. Dis. 2020, 39, 1581-1592. [CrossRef] [PubMed]

113. Dinwiddie, D.L.; Denson, J.L.; Kennedy, J.L. Role of the Airway Microbiome in Respiratory Infections and Asthma in Children Pediatr. Allergy Immunol. Pulmonol. 2018, 31, 236-240. [CrossRef] [PubMed]

114. Berg, G.; Rybakova, D.; Fischer, D.; Cernava, T.; Verges, M.C.; Charles, T.; Chen, X.; Cocolin, L.; Eversole, K.; Corral, G.H.; et al. Microbiome definition re-visited: Old concepts and new challenges. Microbiome 2020, 8, 103. [CrossRef]

115. David, L.A.; Maurice, C.F.; Carmody, R.N.; Gootenberg, D.B.; Button, J.E.; Wolfe, B.E.; Ling, A.V.; Devlin, A.S.; Varma, Y.; Fischbach, M.A.; et al. Diet rapidly and reproducibly alters the human gut microbiome. Nature 2014, 505, 559-563. [CrossRef]

116. Depner, M.; Taft, D.H.; Kirjavainen, P.V.; Kalanetra, K.M.; Karvonen, A.M.; Peschel, S.; Schmausser-Hechfellner, E.; Roduit, C.; Frei, R.; Lauener, R.; et al. Maturation of the gut microbiome during the first year of life contributes to the protective farm effect on childhood asthma. Nat. Med. 2020, 26, 1766-1775. [CrossRef]

117. Giles, E.M.; Couper, J. Microbiome in health and disease. J. Paediatr. Child. Health 2020, 56, 1735-1738. [CrossRef]

118. Lynch, S.V.; Pedersen, O. The Human Intestinal Microbiome in Health and Disease. N. Engl. J. Med. 2016, 375, 2369-2379. [CrossRef] [PubMed]

119. Zhou, Y.; Jackson, D.; Bacharier, L.B.; Mauger, D.; Boushey, H.; Castro, M.; Durack, J.; Huang, Y.; Lemanske, R.F., Jr.; Storch, G.A.; et al. The upper-airway microbiota and loss of asthma control among asthmatic children. Nat. Commun. 2019, 10, 5714. [CrossRef] [PubMed]

120. Durack, J.; Christian, L.S.; Nariya, S.; Gonzalez, J.; Bhakta, N.R.; Ansel, K.M.; Beigelman, A.; Castro, M.; Dyer, A.M.; Israel, E.; et al. Distinct associations of sputum and oral microbiota with atopic, immunologic, and clinical features in mild asthma. J. Allergy Clin. Immunol. 2020, 146, 1016-1026. [CrossRef] [PubMed]

121. Lai, P.S.; Kolde, R.; Franzosa, E.A.; Gaffin, J.M.; Baxi, S.N.; Sheehan, W.J.; Gold, D.R.; Gevers, D.; Xavier, R.J.; Phipatanakul, W The classroom microbiome and asthma morbidity in children attending 3 inner-city schools. J. Allergy Clin. Immunol. 2018, 141, 2311-2313. [CrossRef] [PubMed]

122. Phipatanakul, W.; Bailey, A.; Hoffman, E.B.; Sheehan, W.J.; Lane, J.P.; Baxi, S.; Rao, D.; Permaul, P.; Gaffin, J.M.; Rogers, C.A.; et al The school inner-city asthma study: Design, methods, and lessons learned. J. Asthma 2011, 48, 1007-1014. [CrossRef] [PubMed]

123. Sullivan, A.; Hunt, E.; MacSharry, J.; Murphy, D.M. The Microbiome and the Pathophysiology of Asthma. Respir. Res. 2016, 17, 163. [CrossRef] [PubMed]

124. Bosch, A.; Levin, E.; van Houten, M.A.; Hasrat, R.; Kalkman, G.; Biesbroek, G.; de Steenhuijsen Piters, W.A.A.; de Groot, P.C.M.; Pernet, P.; Keijser, B.J.F.; et al. Development of Upper Respiratory Tract Microbiota in Infancy is Affected by Mode of Delivery. EBioMedicine 2016, 9, 336-345. [CrossRef]

125. Mohajeri, M.H.; Brummer, R.J.M.; Rastall, R.A.; Weersma, R.K.; Harmsen, H.J.M.; Faas, M.; Eggersdorfer, M. The role of the microbiome for human health: From basic science to clinical applications. Eur. J. Nutr. 2018, 57, 1-14. [CrossRef]

126. Kloepfer, K.M.; Lee, W.M.; Pappas, T.E.; Kang, T.J.; Vrtis, R.F.; Evans, M.D.; Gangnon, R.E.; Bochkov, Y.A.; Jackson, D.J.; Lemanske, R.F., Jr.; et al. Detection of pathogenic bacteria during rhinovirus infection is associated with increased respiratory symptoms and asthma exacerbations. J. Allergy Clin. Immunol. 2014, 133, 1301-1307. [CrossRef]

127. Teo, S.M.; Mok, D.; Pham, K.; Kusel, M.; Serralha, M.; Troy, N.; Holt, B.J.; Hales, B.J.; Walker, M.L.; Hollams, E.; et al. The infant nasopharyngeal microbiome impacts severity of lower respiratory infection and risk of asthma development. Cell Host Microbe. 2015, 17, 704-715. [CrossRef]

128. Mansbach, J.M.; Hasegawa, K.; Henke, D.M.; Ajami, N.J.; Petrosino, J.F.; Shaw, C.A.; Piedra, P.A.; Sullivan, A.F.; Espinola, J.A.; Camargo, C.A., Jr. Respiratory syncytial virus and rhinovirus severe bronchiolitis are associated with distinct nasopharyngeal microbiota. J. Allergy Clin. Immunol. 2016, 137, 1909-1913.e1904. [CrossRef] [PubMed]

129. Amat, F.; Plantard, C.; Mulliez, A.; Petit, I.; Rochette, E.; Verdan, M.; Henquell, C.; Labbe, G.; Heraud, M.C.; Evrard, B.; et al. RSV-hRV co-infection is a risk factor for recurrent bronchial obstruction and early sensitization 3 years after bronchiolitis. J. Med. Virol. 2018, 90, 867-872. [CrossRef] [PubMed]

130. Rosas-Salazar, C.; Shilts, M.H.; Tovchigrechko, A.; Schobel, S.; Chappell, J.D.; Larkin, E.K.; Shankar, J.; Yooseph, S.; Nelson, K.E.; Halpin, R.A.; et al. Differences in the Nasopharyngeal Microbiome During Acute Respiratory Tract Infection with Human Rhinovirus and Respiratory Syncytial Virus in Infancy. J. Infect. Dis. 2016, 214, 1924-1928. [CrossRef] [PubMed] 